\title{
Qubits in the pink
}

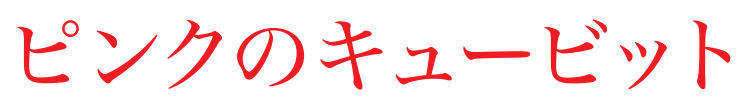

Pieter Kok and Brendon W. Lovett

一部のダイヤモンドは、結晶構造に窒素 - 空孔欠陥とよばれる不完全性があるため、特徵的なピ ンク色を呈している。こうした欠陥を適切に操作することができれば、量子コンピューターの 「キュービット」として利用するというバラ色の展望が開けてくるかもしれない。

Nature Vol. 444 (49) / 2 November 2006

材料科学者である F.C.Franck は「結晶は人間のよう なものであり、久陥があるからこそ興味深い」と述べ た。ダイヤモンドの結晶中にできる負に帯電した「窒 素 - 空孔欠陥」に関する研究成果をPhysical Review Letters 誌に発表した Ronald Hanson とその同僚も、 扮そらく同じ意見であろう ${ }^{1}$ 。の系はみるみるう ちに、固体量子コンピューターの量子情報基本単位 (キュービット) の有力候補になろうとしている。

ダイヤモンドを構成する炭素原子の格子には、窒素 やホウ素など、さまざまな置換不純物原子が入ってい ることがある。こうした欠陥はダイヤモンドに色をつ けるので、しばしば色中心とよばれる。ダイヤモン ドにピンク色を帯びさせる窒素 - 空孔 $(\mathrm{NV})$ 欠陥は、 結晶格子中の空孔の隣に位置する炭素原子が窒素原子 に置き換わることで生じる。2つの欠陌が隣り合つて 存在する可能性は低乞うにみえるかもしれないが、ダ イヤモンドが加熱されると、空孔が格子の中を拡散し ていき、窒素原子の隣に来て止まることが知られてい る。ランダムウォーク」がここで止まるのは、隣り合つ た 2 つの欠陥の配置が非常に安定になるからである。

$\mathrm{NV}$ 中心には、電気的に中性の $\mathrm{NV}^{0}$ と負に帯電し た $\mathrm{NV}^{-}$の 2 種類がある。興味深いのは、電子を余 計にもっている $\mathrm{NV}^{-}$中心の方である。この電子は、 おそらく別の窒素欠陥から供与されたものである。 $\mathrm{NV}^{-}$欠陥の電子のうち、近隣の炭素原子との間に結 合を作っていないものの総数は 6 であり、基底状態 での全スピンは $S=1$ である。このスピンには、磁気 量子数 $m_{S}=+1,0,-1$ によって表さ扎る 3 種類の向
きがある。スピンがこれらのいずれかの值をとる傾向 があるとき、それは偏極しているという。

$\mathrm{NV}^{-}$中心の明確な（「コヒーレント」な）スピン状態 は、長時間（室温でも $50 \mu$ 秒以上 ${ }^{2}$ ) にわたって保存 されうる。 $m_{S}=0$ の状態と $m_{S}= \pm 1$ の状態とのエネルギー 差は、約 $12 \mu \mathrm{eV}$ である。 3 ギガへルツのマイクロ波周 波数の光子は、まさにこのエネルギーをもつているた め、この光を使って $\mathrm{NV}^{-}$中心のスピン状態を操作する ことが可能である。スピン状態の「読み出し」には、もつ と高いエネルギー状態への遷移を利用する。すなわち、 ダイヤモンドにレーザーを照射して遷移を誘発し、緩 和により $\mathrm{NV}^{-}$中心が低いエネルギーレベルへ戻ってく るときに放出する光から、そのスピン状態を知るので ある。この過程は光ルミネッセンスとよばれている ${ }^{3}$

コヒーレンス時間が長く、外部から精確に制御で きる $\mathrm{NV}^{-}$スピンは、実用的なキュービットに求めら れる性質の多くを備えているため、量子コンピュー ティングの分野でさかんに研究されている ${ }^{4}$ 。しかし、 $\mathrm{NV}^{-}$を利用した量子コンピューティングが実現する までには、多くの障害を乗り越えなければならない。 お乞らく最も困難なのは、この系を拡張して多キュー ビット系を構築することである。

Hanson らは、この問題の解決に向かって大きく前 進した ${ }^{1}$ 。彼らは $\mathrm{NV}^{-}$中心と、空孔と結合していな い窒素中心 $\mathrm{N}\left(\mathrm{NV}^{-}\right.$に余分な電子を供与した窒素欠 陥とは異なるもの）とのカップリングを実証した。こ の「N中心」にもスピンがあるが、磁気量子数は異な り、 $m_{S}= \pm 1 / 2$ である。磁場をかけると、 $\mathrm{NV}^{-}$スピン 


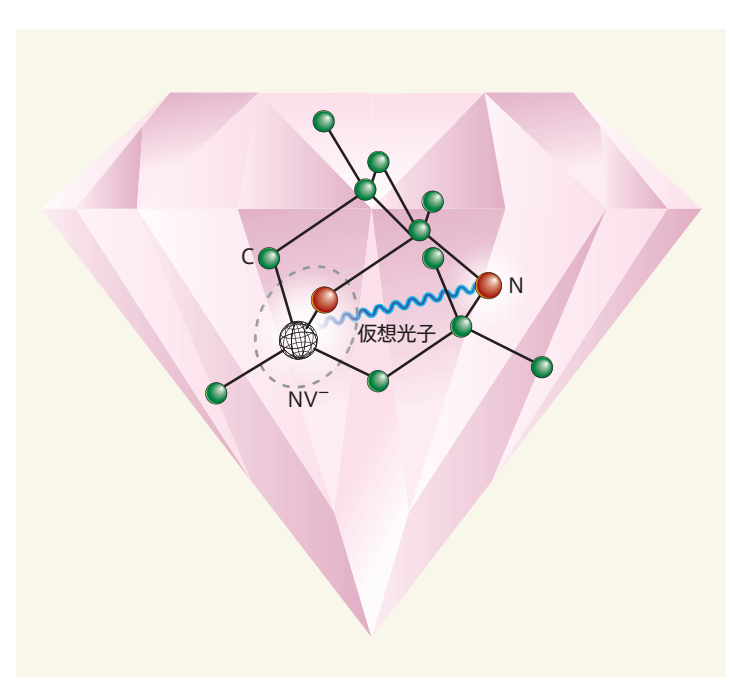

と $\mathrm{N}$ スピンのエネルギーレベルの構造はいずれも変 化する (ゼーマン効果)。ある強さの磁場をかけると、 2つの欠陥のスピンレベルの間のエネルギーギャップ が同じになる。 $\mathrm{NV}^{-}$と $\mathrm{N}$ との間に相互作用がある場 合、この「共鳴」が、いわゆる「仮想光子」を介した エネルギーと偏極の交換を可能にする（図 1)。その 結果、 $\mathrm{NV}^{-}$は光を放出するのに適した量子状態では なくなるため、光ルミネッセンスシグナルが小さくな る。Hanson らが観察したのは、この効果だった ${ }^{1}$ 。

著者らは次に、マイクロ波場を $\mathrm{NV}^{-}$欠陥と共鳴さ せる実験を行った。ここでも、 $\mathrm{NV}^{-}$スピンとマイク ロ波場との間で偏極の交換が起きた。 $\mathrm{NV}^{-}$がダイヤ モンド格子中で孤立している場合、光ルミネッセンス シグナルは 1 回だけ低下するはずである。けれども Hanson らは、シグナル中に 2 回の低下を観察した ${ }^{2}$ 。 これもまた、 $\mathrm{N}$ 中心との相互作用のためである。 $\mathrm{N}$ スピンが 2 つ向きをとりうることで、 $\mathrm{NV}^{-}$中心で の有効磁場に違いが生じ、それに応じて共鳴がシフト する。重要なのは、このシフトが $\mathrm{N}$ 中心のスピン状 態の読み出しを可能にすることである。それには単に、 $\mathrm{NV}^{-}$中心の光ルミネッセンスを観察するだけでよい。 この実験は、必要に応じて $\mathrm{N}$ 中心に特異的な状態を とらせることができることも示している。

$\mathrm{N}$ 中心は、 $\mathrm{NV}^{-}$欠陥を含む試料にはごく一般的に みられるため、上述の相互作用は、 $\mathrm{NV}^{-}$キュービッ トのコヒーレンスが失われる主な原因になっている。 $\mathrm{N}$ 中心を制御する方法は、このデコヒーレンスを許容 範囲内まで小さくする手段として有望視されている。
図 1 : 欠陥どうしのカップリング。Hanson らは実験で、ダイヤ モンドを構成する炭素原子の格子にできる窒素 (N) 欠陷と、そ の近傍にある窒素 - 空孔 $\left(\mathrm{NV}^{-}\right)$欠陥とのカップリングについて 調べた ${ }^{1}$ 。磁場を利用して欠陥のスピン状態のエネルギーを調整 すると、欠陥どうしを共鳴させることができる。このとき、いわ ゆる「仮想光子」を介して、エネルギーと偏極の交換が起こる。 このような相互作用は、 $\mathrm{NV}^{-}$欠陥の光学的制御を利用して窒素 欠陥のスピンを制御することを可能にするものであり、これら を組み合わせてできる系は、量子コンピューティングのための 2 キュービット構造として有望視されている。

$\mathrm{N}-\mathrm{NV}^{-}$系は電子 - スピン 2 キュービット系に相当 するため、今回の実験は、 $\mathrm{NV}^{-}$系に基づく大規模な 量子コンピューターの製作に向けて重要な一歩を踏み 出したものといえる。著者らは、 $\mathrm{N}$ 欠陥の鎖を介して 複数の $\mathrm{NV}^{-}$中心を連結することができると提案する。 この提案は、大胆すぎるかもしれない。多キュービッ トレジスタを実現するには、ある種の「測定に基づく」 量子コンピューティングを利用する方法、すなわち、 キュービット間に量子相関を作ってから量子アルゴリ ズムを実行する方法のほうがよいかもしれない ${ }^{5}$ 。こ こで $\mathrm{N}-\mathrm{NV}^{-}$系は、光学的操作により「ブローカー」 キュービットの間に必要な量子相関を作り出し、これ を「クライアント」キュービット（デコヒーレンス時 間は長いが、光学的遷移を起こさないもの）に移すプ ロトコルとして理想的である ${ }^{6}$ 。この方法がうまくい けば、量子コンピューティングには真にバラ色の未来 が待っているといえるだろう。

PieterKokand Brendon W.Lovett、オックスフォード大学 (英)

1. Hanson, R., Mendoza,F.M., Epstein,R.J. \& Awschalom,D.D. Phys. Rev. Lett 97, 087601(2006)

2. Kennedy,T.A., Colton,J.S., Butler,J.E., Linares,R.C. \& Doering,P.J. Appl. Phys. Lett.83,4190(2003).

3. Jelezko,F., Gaebel,T., Popa,I., Gruber,A. \& Wrachtrup, J. Phys. Rev. Lett. 92 , 076401(2004).

4.Santori,C.etal.preprint available at www.arxiv.org/quant-ph/0607147(2006).

5. Raussendorf,R. \& Briegel, H.J. Phys. Rev. Lett. 86, 5188(2001).

6. Benjamin,S.C., Browne,D.E., Fitzsimons,J. \& Morton,J.J.L. New J. Phys. 8, 141(2006). 